\title{
NITROGEN FIXATION AND GROWTH RESPONSE OF Alnus Rubra FOLLOWING FERTILIZATION WITH UREA OR BIOSOLIDS
}

\author{
Linda S. Gaulke ${ }^{*}$; Charles L. Henry ${ }^{2}$; Sally L. Brown ${ }^{3}$ \\ ${ }^{l}$ Civil and Environmental Engineering, University of Washington - 333 More Hall/Box 352700 - Seattle, WA - \\ 98195-2700 - USA. \\ ${ }_{3}^{2}$ Interdisciplinary Arts and Sciences, University of Washington, Bothell Campus - USA. \\ ${ }^{3}$ College of Forest Resources, University of Washington - Box 352100 - Seattle, WA - 98195 - USA. \\ *Corresponding author $<$ lsg@u.washington.edu $>$
}

\begin{abstract}
Nitrogen fertilization of forests using biosolids offers a potentially environmentally friendly means to accelerate tree growth. This field study was designed to analyze the effects of nitrogen fertilization on the symbiotic, nitrogen (N)-fixing relationship between Alnus rubra Bong. (red alder) and Frankia. Anaerobically digested, class B biosolids and synthetic urea $(46 \% \mathrm{~N})$ were applied at rates of 140,280 and $560 \mathrm{~kg} \mathrm{ha}^{-1}$ available $\mathrm{N}$ to a well-drained, sandy, glacial outwash soil in the Indianola series (mixed, mesic Dystric Xeropsamments). Plots were planted with A. rubra seedlings. At the end of each of two growing seasons trees were harvested and analyzed for the rate of $\mathrm{N}$ fixation (as acetylene reduction activity), biomass and foliar $\mathrm{N}$. At year 1, there was no $\mathrm{N}$ fixation for trees grown with urea amendments, but control $\left(17 \mu \mathrm{mol} \mathrm{C}_{2} \mathrm{H}_{4} \mathrm{~g}^{-1} \mathrm{hr}^{-1}\right)$ and biosolids $\left(26-45 \mu \mathrm{mol} \mathrm{C}_{2} \mathrm{H}_{4} \mathrm{~g}^{-1} \mathrm{hr}^{-1}\right)$ trees were fixing $\mathrm{N}$. At the end of year 2, all trees in all treatments were fixing $\mathrm{N}\left(7 \mu \mathrm{mol} \mathrm{C}_{2} \mathrm{H}_{4} \mathrm{~g}^{-1} \mathrm{hr}^{-1}, 4-16 \mu \mathrm{mol} \mathrm{C}_{2} \mathrm{H}_{4} \mathrm{~g}^{-1}\right.$ $\mathrm{hr}^{-1}$, and 20-29 $\mathrm{mmol} \mathrm{C}_{2} \mathrm{H}_{4} \mathrm{~g}^{-1} \mathrm{hr}^{-1}$ for control, urea and biosolids respectively). Trees grown with biosolids amendments were larger overall (year 1 shoot biomass $10 \mathrm{~g}, 5 \mathrm{~g}$, and $23 \mathrm{~g}$ for control, urea, and biosolids respectively, year 2 shoot biomass $50 \mathrm{~g}, 51 \mathrm{~g}$, and $190 \mathrm{~g}$ for control, urea, and biosolids respectively) with higher concentrations of foliar $\mathrm{N}$ for both years of the study (year 1 foliar $\mathrm{N} 26 \mathrm{~g} \mathrm{~kg}^{-1}$, $27 \mathrm{~g} \mathrm{~kg}^{-1}$, and $40 \mathrm{~g} \mathrm{~kg}^{-1}$ for control, urea, and biosolids respectively, year 2 foliar $\mathrm{N} 17 \mathrm{~g} \mathrm{~kg}^{-1}, 19 \mathrm{~g} \mathrm{~kg}^{-1}$, and $23 \mathrm{~g} \mathrm{~kg}^{-1}$ for control, urea, and biosolids respectively). Trees grown with urea amendments appeared to use the urea $\mathrm{N}$ over Frankia supplied N, whereas the biosolids trees appeared to be able to use both $\mathrm{N}$ in biosolids and $\mathrm{N}$ from Frankia. The results from this study indicated that the greater growth of $A$. rubra may have been responsible for the observed higher $\mathrm{N}$ demand. Biosolids may have supplied other nutrients to the trees to support this accelerated growth.
\end{abstract}

Key words: Frankia, acetylene reduction activity (ARA)

\section{FIXAÇÃO DE NITROGÊNIO E CRESCIMENTO DE Alnus Rubra FERTILIZADO COMURÉIAOU BIOSÓLIDOS}

RESUMO: A fertilização nitrogenada de florestas com biosólidos constitui um meio de aceleração do crescimento das plantas potencialmente não impactante ao meio. Os efeitos de fertilização de nitrogênio atmosférico na relação simbiôntica e de fixação de nitrogênio Alnus rubra Bong. (amieiro vermelho) e Frankia foram avaliados em um estudo de campo. Biosólidos classe B digeridos anaerobicamente e uréia sintética $(46 \% \mathrm{~N})$ foram aplicados a taxas de 140, 280 e $560 \mathrm{~kg} \mathrm{ha}^{-1}$ de $\mathrm{N}$ disponível em um solo tipo Areia Quartzosa. Ao contrário das plantas do grupo controle $\left(17 \mu \mathrm{mol} \mathrm{C}_{2} \mathrm{H}_{4} \mathrm{~g}^{-1} \mathrm{hr}^{-1}\right)$ ou fertilizadas com biosólidos (26-45 $\left.\mu \mathrm{mol} \mathrm{C}_{2} \mathrm{H}_{4} \mathrm{~g}^{-1} \mathrm{hr}^{-1}\right)$, plantas fertilizadas com uréia não apresentavam fixação de nitrogênio após um ano de cultivo. Ao final do segundo ano, todas as árvores em todos os tratamentos fixavam $\mathrm{N}\left(7 \mu \mathrm{mol} \mathrm{C}_{2} \mathrm{H}_{4} \mathrm{~g}^{-1} \mathrm{hr}^{-1}\right.$; 4-16 $\mu \mathrm{mol} \mathrm{C}_{2} \mathrm{H}_{4} \mathrm{~g}^{-1} \mathrm{hr}^{-1}$; e 20-29 $\mu \mathrm{mol} \mathrm{C}_{2} \mathrm{H}_{4} \mathrm{~g}^{-1} \mathrm{hr}^{-1}$ para controle, uréia e biosólidos, respectivamente). Plantas cultivadas sob remediação com biosólidos apresentaram maior biomassa na parte aérea ao final do ano 2 (50 g; $51 \mathrm{~g}$; e $190 \mathrm{~g}$ para controle, uréia, e biosólidos, respectivamente), e também maiores concentrações de nitrogênio foliar em ambos os períodos analisados ( $\mathrm{N}$ foliar no ano 1 - $26 \mathrm{~g} \mathrm{~kg}^{-1}, 27 \mathrm{~g} \mathrm{~kg}^{-1}$, e $40 \mathrm{~g} \mathrm{~kg}^{-1}$; $\mathrm{N}$ foliar no ano $2-17 \mathrm{~g} \mathrm{~kg}^{-1}, 19 \mathrm{~g} \mathrm{~kg}^{-1}$, and $23 \mathrm{~g} \mathrm{~kg}^{-1}$, respectivamente para controle, uréia e biosólidos). A maior taxa de crescimento de $A$. rubra pode ter resultado em maior exigência em $\mathrm{N}$ e os biosólidos supriram quantidades adicionais de nutrientes capazes de sustentar o crescimento acelerado.

Palavras-chave: Frankia, atividade da redução de acetileno (ARA) 


\section{INTRODUCTION}

Traditionally, commercial forestry has been managed without consideration of potential impacts on forest ecosystems. One example of this is the impact of forest nitrogen $(\mathrm{N})$ fertilization, with synthetic fertilizers or municipal biosolids, on the atmospheric $\mathrm{N}$ fixation in forests. Alnus rubra is an important hardwood in forests on the Pacific Coast of North America and is frequently found in Pseudotsuga menziesii (Douglas fir) plantations. A. rubra forms a symbiotic N fixing relationship with Frankia which complicates the determination of appropriate rates of synthetic $\mathrm{N}$ or biosolids $\mathrm{N}$ to maximize growth while simultaneously preventing environmental contamination (Henry et al., 2000).

It is difficult to predict how $A$. rubra will react to the addition of $\mathrm{N}$ from biosolids, as there has been scant research on fertilization of Alnus sp. with $\mathrm{N}$. For other plant species that form symbiotic $\mathrm{N}$ fixing relationships, the addition of $\mathrm{N}$ fertilizer has been shown to slow or stop $\mathrm{N}$ fixation rates (Voison et al., 2002), which then increase upon the subsequent removal of the N source (Fujikake et al., 2002). Available $\mathrm{N}$ can also reduce nodule frequency and size (Daimon \& Yoshioka, 2001). There have been studies illustrating similar effects with Alnus (Côté \& Dawson, 1989; Martin et al., 2003). However, there is also the potential that Alnus would utilize both symbiotic and added sources of $\mathrm{N}$ if plant demand for $\mathrm{N}$ was sufficiently strong (Troelstra et al., 1992). Biosolids soil amendments have increased growth and nodulation of Vicia sativa (Vetch) (Sidiras et al., 1999), and Glycine $\max$ (soybeans) (Vieira, 2001). In studies looking at Alnus, $\mathrm{N}$ additions as $\mathrm{NO}_{3}^{-}, \mathrm{NH}_{4}^{+}$, and $\mathrm{NH}_{4} \mathrm{NO}_{3}$ increased biomass of A. glutinosa (Troelstra et al., 1992), and $\mathrm{N}$ additions did not reduce $\mathrm{N}$ fixation in $A$. incana unless the system $\mathrm{N}$ demand was exceeded (Rytter et al., 1991).

This study was conducted to evaluate what the effect of $\mathrm{N}$ from urea and biosolids would be on the symbiotic $\mathrm{N}$ fixing relationship of Alnus-Frankia, and if increased growth yields would result from these $\mathrm{N}$ additions.

\section{MATERIALS AND METHODS}

\section{Study Site Description}

This study was conducted at a research forest in Eatonville, Washington, US $\left(47^{\circ} 37^{\prime} \mathrm{N}, 122^{\circ} 19^{\prime} \mathrm{W}\right)$ at the base of the Cascade Mountain foothills. Average annual rainfall is $1200 \mathrm{~mm}$, with the rainfall from July and August typically being less than $120 \mathrm{~mm}$ (Pack Forest precipitation records). The study site is $317 \mathrm{~m}$ above sea level. The soil is a well-drained, sandy, glacial outwash soil in the Indianola series (mixed, mesic Dystric Xeropsamments) (NRCS, 2004).

\section{Study Installation}

Prior to installation in February 2002 the site was densely vegetated with Cytisus scoparius (Scotch Broom) and A. rubra. The area was cleared of vegetation and the soil was disked to break up any remaining roots for removal. Nitrogen was provided in two forms; synthetic urea $\left[46 \% \mathrm{~N}\left(\mathrm{CO}\left(\mathrm{NH}_{2}\right)_{2}\right)\right]$ (urea), and class $\mathrm{B}$, anaerobically digested biosolids with available and total $\mathrm{N}$ content of $14 \mathrm{~g} \mathrm{NH}_{3} \mathrm{~kg}^{-1}$ and $63 \mathrm{~g} \mathrm{~N} \mathrm{~kg}^{-1}$, respectively (King County Environmental Laboratory, March 2002). A control treatment was also included in the experimental design.

Biosolids application rates were calculated based on the method used by King County for their biosolids forest application sites (Henry et al., 1999). This method considers $\mathrm{N}$ uptake by trees and understory, soil immobilization and potential for volatilization. For this site consideration of these factors resulted in a biosolids application of $13.4 \mathrm{Mg} \mathrm{ha}^{-1}$ which provided $140 \mathrm{~kg} \mathrm{ha}^{-1}$ available N. In comparison, recommended available $\mathrm{N}$ rates for the first two years growth of hybrid cottonwood (Populus L.; do not fix N) are $195 \mathrm{~kg} \mathrm{ha}^{-1}$ (Henry et al., 1999). In addition to the rate calculated to meet the $\mathrm{N}$ needs of the stand, biosolids and urea were added at $2 \mathrm{x}$ and $4 \mathrm{x}$ this amount. The study was designed as a randomized complete block with three replicates. Plots were each $2 \mathrm{~m} \times 2 \mathrm{~m}$. There was a $1 \mathrm{~m}$ space between adjoining plots as well as a $3 \mathrm{~m}$ work row between each block. The closest distance between trees in adjoining plots was $2 \mathrm{~m}$.

Amendments were applied evenly to the surface of each plot and then rototilled to a depth of 15$20 \mathrm{~cm}$. Nine bare-root A. rubra Bong. seedlings, 40$50 \mathrm{~cm}$ in height, were planted in each plot evenly spaced in a square grid pattern, with a $0.5 \mathrm{~m}$ buffer between the outermost trees and the edge of the plot. There were 27 trees planted for each treatment ( 9 per plot $\times 3$ plots per treatment). The seedlings were obtained from a local nursery and had been grown from seed stock from lowlands in Whatcom and Skagit counties. At the time of planting, the whips had sparse and small nodules and no leaves.

\section{Maintenance}

To eliminate any additional competition for soil available $\mathrm{N}$ weeds within each plot area were killed by direct application of glyphosate herbicide to foliage with a wick applicator. The area surrounding plots was mowed to discourage additional weeds. Deer browsing of $A$. rubra foliage was initially controlled by biocontrol methods. In December 2002, a 2.5 m chain 
link fence was built surrounding the entire study and this eliminated access for deer. After the first growing season, plots were thinned so that a maximum of 4 trees remained in each plot. This was done to reduce competition between trees as they grew.

\section{Soil/Biosolids Sampling}

Soil samples were collected prior to amendment application, as well as during tree harvest in September 2002 and August 2003. Soil samples were collected with a stainless steel probe $(2.5 \mathrm{~cm}$ diameter) in the $0-15 \mathrm{~cm}$ depth range. Three samples were taken from each plot and homogenized. Samples were kept on ice or refrigerated until return to the laboratory when the available $\mathrm{N}$ analysis was performed using field moist samples that were sieved to $<2 \mathrm{~mm}$; all other analyses were conducted using air-dried samples that had been sieved to $<2 \mathrm{~mm}$. Prior to installation total carbon $(\mathrm{C})$ and $\mathrm{N}$ were determined by combustion and total phosphorus $(\mathrm{P})$ was determined by soil acid-peroxide digestion method for sediments, sludges, and soils (USEPA, 1986) on a per plot basis. Average C content of soils prior to amendment addition was $2 \pm$ $0.3 \mathrm{~g} \mathrm{~kg}^{-1}$. Total $\mathrm{N}$ content was $0.1 \pm 0.001 \mathrm{~g} \mathrm{~kg}^{-1}$ with total $\mathrm{P}$ equal to $428 \pm 25 \mathrm{mg} \mathrm{kg}^{-1}$.

\section{Available Nitrogen and phosphorus}

Potassium chloride $(\mathrm{KCl})$ extraction was used to determine available $\mathrm{N}\left(\mathrm{NO}_{2}^{-}, \mathrm{NO}_{3}{ }^{-}\right.$and $\left.\mathrm{NH}_{4}{ }^{+}\right)$ (Keeney \& Nelson, 1982; Robertson et al., 1999). Five grams of soil were placed in a glass flask with $50 \mathrm{~mL}$ $2 \mathrm{M} \mathrm{KCl}$. The flasks were placed on a shaker for one hour, left to settle, and then filtered through Whatman No. 41 filter paper. The solution was analyzed with a Lachat flow injection analyzer using QuickChem method 107-04-1-B for $\mathrm{NO}_{3}^{-} / \mathrm{NO}_{2}^{-}$, and 10-107-06-1$\mathrm{F}$ for $\mathrm{NH}_{4}^{+}$. Ammonium nitrate $\left(\mathrm{NH}_{4} \mathrm{NO}_{3}\right)$ solution standards were used to calibrate for solution concentrations of $\mathrm{NO}_{3}^{-}$and $\mathrm{NH}_{4}^{+}$from 0 to $1000 \mu \mathrm{g} \mathrm{L}^{-1}$ (calibration curve coefficient $=0.99$ ). Soil water content data were used to correct for percent moisture of field moist samples.

Available $\mathrm{P}$ was determined using the Bray method (Kuo, 1996). Twenty mLs of dilute acid solution were added to $1 \mathrm{~g}$ of air dried soil. The mixture was shaken for 2 minutes and then filtered through Whatman No. 40 filter paper. Total P in the extracts was determined on a Lachat flow injection analyzer.

\section{pH}

Soils slurries were mixed 1:1 on a volume basis with deionized water and air-dried soil samples and then left to stabilize. The $\mathrm{pH}$ was measured after one hour with an Orion pH meter (Bremner, 1996; Nelson \& Sommers, 1996).

\section{Total Carbon and Nitrogen}

Soil samples were ground with a mortar and pestle and placed into foil packages on a CAHN C-33 microbalance. Total $\mathrm{C}$ and $\mathrm{N}$ were determined using a CE-440 elemental analyzer, at $980^{\circ} \mathrm{C}$ (Bremner, 1996; Nelson \& Sommers, 1996). National Institute of Standards and Technology (NIST) standards "Montana soil" and "sludge standard", along with acetanilide and benzoic acid as internal standards, were routinely included in analysis. Respective rates of recovery for standards were; 0.89-0.96 (C, Montana soil), 0.951.06 (N, sludge standard), 0.94-1.01 (C, acetanilide), 0.94-0.96 ( $\mathrm{N}$, acetanilide), 0.98 (C, benzoic acid). Total $\mathrm{C}$ and $\mathrm{N}$ were reported as \% based on a dry weight basis, and the $\mathrm{C}: \mathrm{N}$ ratio as weight:weight.

\section{Nitrogen Fixation}

There are advantages and deficiencies to every method for measurement of symbiotic $\mathrm{N}$ fixation. Methods reported in the literature include $15 \mathrm{~N}$ isotope dilution (Busse, 2000), 15N natural abundance (Shearer et al., 1983), 15N incorporation (McNeill et al., 1997), $\mathrm{N}$ accretion (Rothe et al., 2002), and acetylene reduction activity (ARA) (Hardy et al., 1973). As the goal of this study was to evaluate the impact of treatments on Frankia, and not to determine cumulative amounts of $\mathrm{N}$ fixation, ARA was selected as the most convenient method of analysis (Myrold et al., 1999). ARA has been shown to be a sensitive method for comparison of relative rates of $\mathrm{N}$ fixation (Weaver \& Danso, 1994). Other methods such as isotope dilution are complicated by the need for a non-fixing reference plant that has similar growth patterns to the unique, rapid growth habits of Alnus spp. (Busse, 2000). In situ methods (e.g. split-root systems, cuvettes) are more readily carried out in the laboratory and are not necessarily appropriate for field studies. For this study, foliar $\mathrm{N}$ was used in addition to ARA to evaluate the nitrogen balance between control and fertilized treatments.

Relative rates of $\mathrm{N}$ fixation were measured as ARA and reported as micromoles $\mathrm{C}_{2} \mathrm{H}_{4}$ produced per gram of nodule used in the assay (dry weight basis) per hour ( $\mu \mathrm{mol} \mathrm{C}_{2} \mathrm{H}_{4} \mathrm{~g}^{-1} \mathrm{~h}^{-1}$ ) as described in Hardy et al. (1973). Two trees from each plot were harvested for analyses during the first week of September in 2002, and the last week of August in 2003. The values from both trees were averaged and treated as a single sample for statistical analysis. This time of year was selected for tree harvesting to allow for a reasonably complete growing season for comparison of biomass. In addition, it was determined based on reported midday observations of $A$. rubra ARA in July (34.9 $\left.\mu \mathrm{mol} \mathrm{g}{ }^{-1} \mathrm{hr}^{-1}\right)$, September $\left(20.9 \mu \mathrm{mol} \mathrm{g}^{-1} \mathrm{hr}^{-1}\right)$ and Janu- 
ary $\left(0.1 \mu \mathrm{mol} \mathrm{g}^{-1} \mathrm{hr}^{-1}\right)$ (Teklehaimanot \& Martin, 1999) that ARA would be sufficiently high at this time. Replicate blocks were analyzed on consecutive days at the same time of the day to account for diurnal variations. Tree roots were dug up with a garden fork and soil was lightly brushed off. A random selection of nodules was removed from roots with a razor knife, keeping a portion of the root intact to ensure that damage did not occur to nodules, and placed into a $65 \mathrm{~mL}$ glass vial, which was then sealed with rubber septa. $6.5 \mathrm{~mL}$ air was removed from the vial and then $6.5 \mathrm{~mL}$ acetylene $\left(\mathrm{C}_{2} \mathrm{H}_{2}\right)$ was added ( $10 \%$ by volume), and the head space was mixed well. Positive controls (nodules, no $\left.\mathrm{C}_{2} \mathrm{H}_{2}\right)$ and negative controls $\left(\mathrm{C}_{2} \mathrm{H}_{2}\right.$, no nodules) were included. The reaction was left to run for three hours in the dark and then a $3 \mathrm{ml}$ sample was taken from each vial and stored in a vacutainer for transport to the laboratory. Samples were analyzed for ethylene $\left(\mathrm{C}_{2} \mathrm{H}_{4}\right)$ on a SRI $8610 \mathrm{C}$ gas chromatograph (GC) with a $60 \mathrm{~m} \times$ 0.53 Supelco capillary column, using manual injection with nitrogen as the carrier gas (Hardy et al., 1973; Myrold et al., 1999; Weaver \& Danso, 1994). Detection limits for this analysis, taking dilution into account, were $1.5 \mu \mathrm{mol} \mathrm{g} \mathrm{hr}^{-1}$. Soil moisture and temperature were also determined for each plot at the time of ARA sampling to account for potential variability.

\section{Biomass}

Whole trees were harvested for biomass determination. Shoots and roots were separated at the soil line for root and shoot biomass measurements in 2002. All nodules were brushed to remove soil and removed from roots for separate biomass measurements. Although multiple plants were harvested per plot, the biomass measures of the plants were averaged and a single average value was used for statistical analysis. Plants were oven-dried for 72 hours at $70^{\circ} \mathrm{C}$. Biomass was reported as dry weight in grams. Two trees were harvested from each plot the first year of the study. For the second year only shoots were harvested as dry cemented soil conditions made it difficult to accurately collect the entire root and nodule system for determination of total biomass. Mean \pm standard deviation is reported in the text.

\section{Total Foliar Nitrogen}

Three leaves were randomly selected from each tree to comprise one composite sample for both trees collected from each plot. Samples were ovendried, ground and then analyzed for total $\mathrm{N}$ on a CE440 elemental analyzer as described for soils (Bremner, 1996; Nelson \& Sommers, 1996). NIST plant standards as well as acetanilide and benzoic acid as internal standards were included in analysis. Respective rates of recovery for standards were; 0.96-1.01 $(\mathrm{N}$, citrus leaves), 0.94-1.01 (C, acetanilide), 0.94-0.96 (N, acetanilide), 0.98 (C, benzoic acid). Mean \pm standard deviation is reported in the text.

\section{Statistical Analysis}

Statistical analyses were performed using SPSS 12 for Windows (SPSS Inc, 2003). Data was checked for normality by visual inspection and confirmed using Kolmogorov-Smirnov tests. Analysis of variance (ANOVA) was used to test for main effects of treatment and treatment versus rate interactions. There was a small block effect for both foliar $\mathrm{N}$ and total soil $\mathrm{C}$ the first year and no significant block effects for the second year of the study. There were no block versus treatment interactions for either year. Means were separated using Duncan's multiple range test $(P=0.05)$. Linear regression was used to evaluate relationships between treatment rate and measured properties, and correlation was evaluated among measured properties $(P=0.05)$.

\section{RESULTS AND DISCUSSION}

\section{Soil Properties}

At the end of the first growing season (Table 1) both urea and biosolids treatments had higher levels of available $\mathrm{N}$ than the control. $\mathrm{NO}_{3}^{-}$concentrations were similar for biosolids and urea for each treatment, with soil $\mathrm{NH}_{4}^{+}$concentrations overall being lower for urea than biosolids. As expected, almost the entire $\mathrm{N}$ from urea application was in the form of plant available N (PAN) for the first year of the study and had dissipated by the second year. There was a slight decrease in the $\mathrm{C}: \mathrm{N}$ ratio for almost every treatment from the first to the second year. The first year soil $\mathrm{pH}$ values for urea and biosolid treatments were both lower than that of the control, while in the second year the biosolids $\mathrm{pH}$ was lower than both the control and urea. The lowest $\mathrm{pH}$ was in the year 2 biosolids $560 \mathrm{~kg} \mathrm{ha}^{-1}$ treatment $(\mathrm{pH}=4.9)$ as compared to the highest in the year 2 control $(\mathrm{pH}=5.8)$. Plant available $\mathrm{P}$ was higher in all of the biosolids treatments than in the control or urea treatments. This is to be expected as biosolids contain high levels of $\mathrm{P}$ in addition to $\mathrm{N}$. The extractable $\mathrm{P}$ in the biosolid amended soils are considered optimal for plant growth, whereas the $\mathrm{P}$ in the urea and control soils were below optimal levels, potentially indicating deficiency (SERA-IEG 17, 2000).

\section{Nitrogen fixation and nodule biomass}

At the time of the first year tree harvest, $\mathrm{N}$ fixation activity as ARA was below detection limits for all trees grown with urea amendments (Figure 1). Rates of ARA for trees grown in biosolid treatments (26-45 $\left.\mu \mathrm{mol} \mathrm{C}_{2} \mathrm{H}_{4} \mathrm{~g}^{-1} \mathrm{hr}^{-1}\right)$ were higher than control trees (17 
Table 1 - Mean \pm standard deviation for soil $\mathrm{NO}_{3}^{-}, \mathrm{NH}_{4}^{+}$, total $\mathrm{C}, \mathrm{N}$, and $\mathrm{C}: \mathrm{N}$ by treatment type and rate for both years. Biosolids were applied at rates to provide equivalent available $\mathrm{N}$ as the Urea.

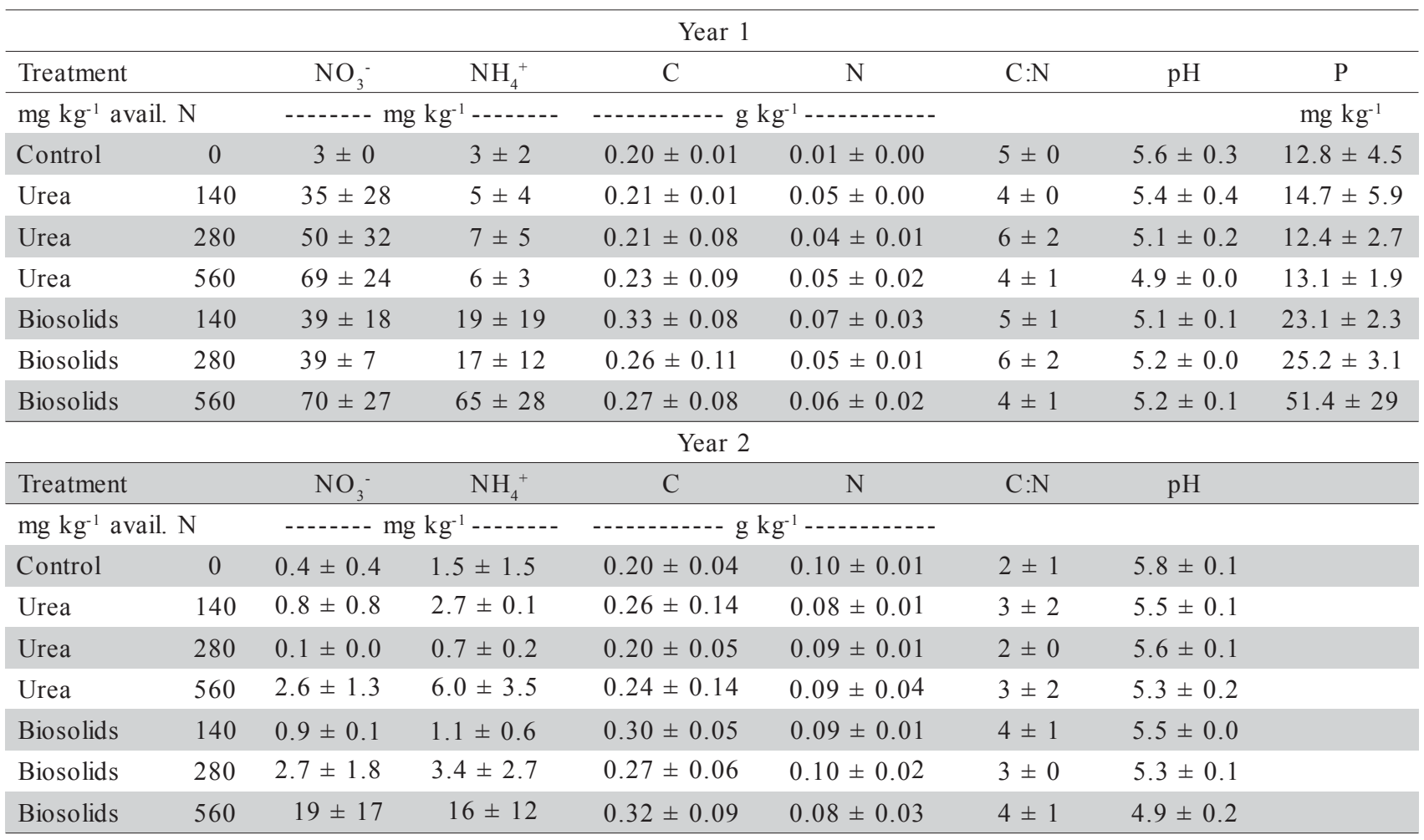

$\mu$ mol $\left.\mathrm{C}_{2} \mathrm{H}_{4} \mathrm{~g}^{-1} \mathrm{hr}^{-1}\right)$, but high variability precluded these differences from being statistically defensible $(P=$ $0.05)$. Nodule biomass followed a similar pattern to ARA with the trees grown in urea $(0.05 \pm 0.03 \mathrm{~g})$ and control treatments $(0.13 \pm 0.06 \mathrm{~g})$ being smaller, and biosolid treatments larger $(0.20 \pm 0.10 \mathrm{~g})$. In the first year total nodule biomass correlated positively to ARA $\left(r^{2}=0.60\right)$. However, there was no relationship between the amount of amendment to nodule biomass or ARA. The absence of any detectable $\mathrm{N}$ fixation (as ARA), together with the smaller nodule biomass of trees grown in urea amended soils, was most likely a result of available $\mathrm{N}$ in the soil inhibiting $\mathrm{N}$ fixation and nodulation. This effect has been well documented for Alnus species (Huss-Danell et al., 2001; Martin et al., 2003; Wall et al., 2000).

At the time of the second year tree harvest, when $\mathrm{N}$ had dissipated from the urea treatments, rates of $\mathrm{N}$ fixation in the urea treatments increased to 4-16 $\mu \mathrm{mol} \mathrm{C}_{2} \mathrm{H}_{4} \mathrm{~g}^{-1} \mathrm{hr}^{-1}$. ARA for control trees was $7 \mu \mathrm{mol}$ $\mathrm{C}_{2} \mathrm{H}_{4} \mathrm{~g}^{-1} \mathrm{hr}^{-1}$ and biosolids 20-29 $\mu \mathrm{mol} \mathrm{C}_{2} \mathrm{H}_{4} \mathrm{~g}^{-1} \mathrm{hr}^{-1}$. Differences between type of treatments were not statistically different $(P=0.05)$, but ARA activity in the urea amendments increased proportionally with the amount of treatment applied in the first year $\left(\mathrm{r}^{2}=0.70\right.$, $P=0.05)$. Where ARA was inhibited the first year for the urea trees, the second year trees were fixing $\mathrm{N}$ at rates similar to the control soils. ARA for trees grown

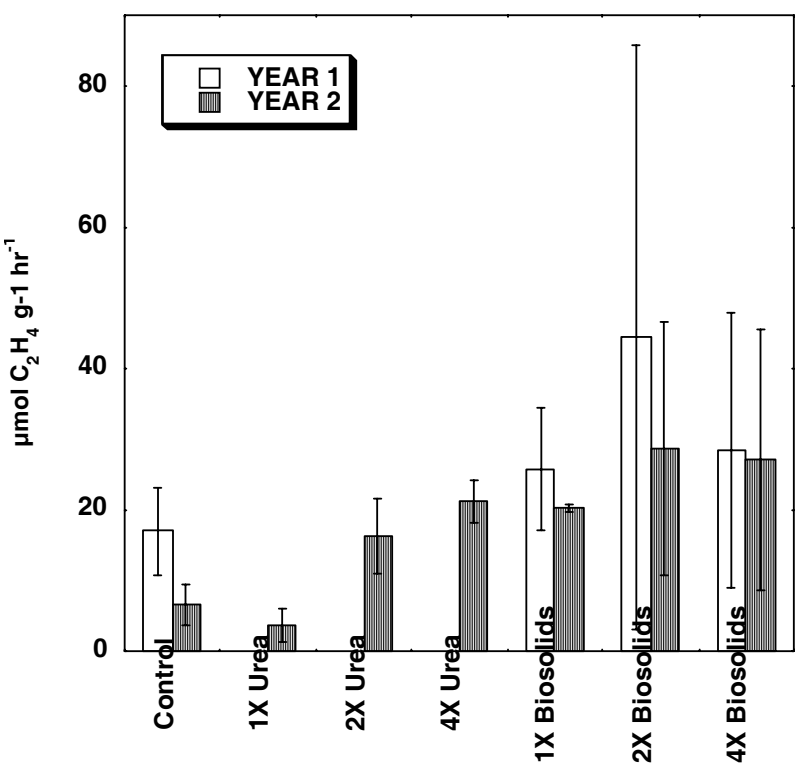

Figure 1 - Nitrogen fixation by Frankia as measured by acetylene reduction activity (ARA) for Alnus rubra fertilized with urea or municipal biosolids applied to provide one, two or four times the estimated $\mathrm{N}$ demand. Data, means and standard deviation are shown for both years.

in the biosolid treatments were not inhibited by available $\mathrm{N}$ in either year of the study. This was the case even though the biosolids and urea amendments were designed to provide the same amounts of available $\mathrm{N}$. These results can potentially be explained by consid- 
ering the other nutrients included in the biosolids. In particular, N, P and the ratio between them have been found to increase nodulation and $\mathrm{N}$ fixation in actinorhizal species. Studies growing actinorhizal species in solution have found $\mathrm{N}$ to be an inhibiter and $\mathrm{P}$ a promoter of nodule growth (Wall et al., 2000). In addition, at low $\mathrm{P}$ concentrations such as those observed in the control and urea treatments, soil $\mathrm{N}$ inhibits nodule size and number, but at high $\mathrm{P}$ concentrations $\mathrm{N}$ stimulates nodule growth (Gentili \& HussDanell, 2003; Huss-Danell et al., 2001). In a field study on the Tanana River floodplain $\mathrm{N}$ fixation of $A$. tenuifolia was found to be $\mathrm{P}$ limited at total $\mathrm{P}$ concentrations of $79 \mathrm{~g} \mathrm{~m}^{-2}$ (depth of $20 \mathrm{~cm}$ ) (Uliassi \& Ruess, 2002). Phosphorus fertilization increased nodule biomass and resulted in a $138 \%$ increase in $A$. tenuifolia $\mathrm{N}$ fixation. Based on the $\mathrm{N}$ fixation observed in the biosolid treatments, our results suggest that the $\mathrm{P}$ in the biosolids was a factor in increasing $\mathrm{N}$ fixation.

\section{Shoot biomass}

The average shoot biomass at the time of the first years sampling were $5 \pm 2 \mathrm{~g}$ for trees grown in urea and $10 \pm 8 \mathrm{~g}$ for the control trees, with the biosolids trees being larger $23 \pm 11 \mathrm{~g}$ than the urea and control trees (Figure 2). There was a weak correlation between total biomass and rates of ARA $\left(\mathrm{r}^{2}=\right.$ $0.49)$. At the second year harvest the differences in shoot biomass between trees grown in the biosolids amended soils and the other treatments were again very pronounced, with the control and urea treatments be-

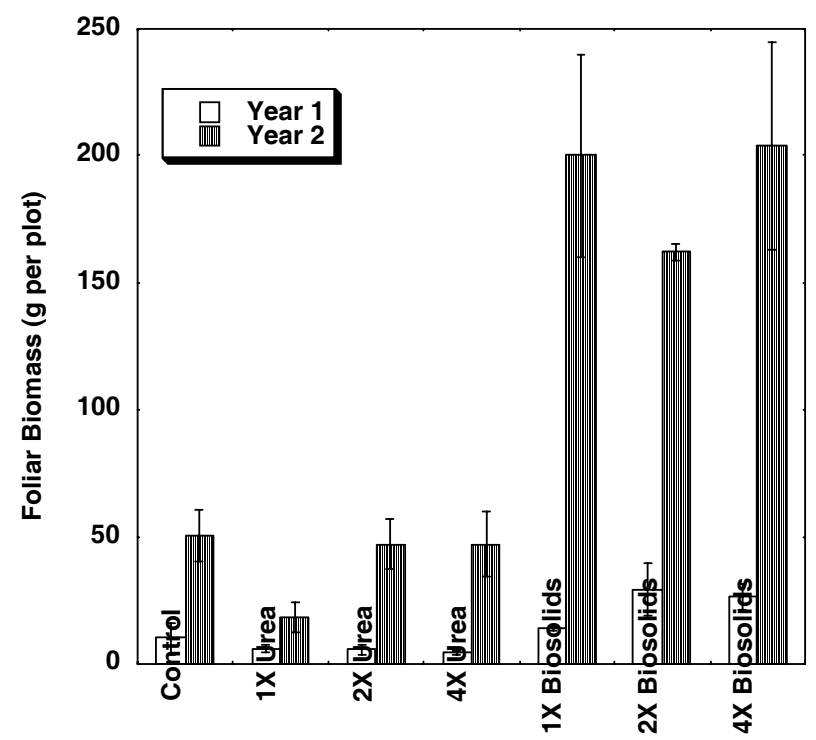

Figure 2 - Foliar biomass for Alnus rubra fertilized with urea or municipal biosolids applied to provide one, two or four times the estimated $\mathrm{N}$ demand. Means and standard deviation are shown for both harvests with two trees harvested per plot per year. ing smaller $(190 \pm 45 \mathrm{~g}$ biosolids, $50 \pm 14 \mathrm{~g}$ control and $51 \pm 38 \mathrm{~g}$ urea). No correlation was seen between shoot biomass and ARA, although in other studies $A$. rubra biomass has frequently been seen to correlate to ARA (Monaco et al., 1982; Rojas et al., 2002).

Shoot biomass decreased with increasing amount of urea amendment, while shoot biomass of trees grown with biosolids amendments were 2 to 5 times larger than control and urea treatments. Observed yield increases were similar across all rates of biosolid additions. Total $\mathrm{P}$ in the biosolids used in this study was $26.7 \mathrm{~g} \mathrm{~kg}^{-1}$ and plant available $\mathrm{P}$ in all biosolid treatments was greater than or equal to 25 $\mathrm{mg} \mathrm{kg}{ }^{-1}$. Plant available $\mathrm{P}$ in all other treatments averaged $13.3 \mathrm{mg} \mathrm{kg}^{-1}$ which is below optimal levels for plant growth (SERA-IEG 17, 2000). At the lowest application rate $\left(6 \mathrm{Mg} \mathrm{ha}^{-1}\right)$, the biosolids provided $161 \mathrm{~kg} \mathrm{P} \mathrm{ha}{ }^{-1}$. Although recent studies have demonstrated that the phytoavailable fraction of total $\mathrm{P}$ in biosolids varies based on biosolids treatment, results from this study suggest that $\mathrm{P}$, or other nutrients provided by the biosolids, may have been the factor responsible for the high growth and subsequent high $\mathrm{N}$ demand in trees grown in these treatments (O'Connor et al., 2004).

A growth response has been seen when $\mathrm{P}$ is added to nitrogen fixing plants, but it is unknown whether or not the P limitation is due to nodulation and nodule function of the symbiotic relationship (Gentili \& Huss-Danell, 2003; Olivera et al., 2004), or the host plant demand for P (Reddell et al., 1997). Binkley et al. (2003) found P fertilization of Facaltaria moluccana (actinorhizal tree) to increase both the seedling biomass by $75 \%$ and $\mathrm{N}$ fixation by $100 \%$. Rojas et al. (2002) found the addition of macronutrients $(\mathrm{P}, \mathrm{K}, \mathrm{Ca}, \mathrm{Mg})$, combined with inoculation of A. rubra with Frankia, to also increase both rates of ARA and biomass.

Total $\mathrm{P}$ concentration in the soil for this study was $428 \mathrm{mg} \mathrm{kg}^{-1}$ and phytoavailable $\mathrm{P}$ was below optimal levels. In another study also conducted on a gravelly, sandy loam, Indianola series soil, Compton \& Cole (1998) found total soil P in a 50 year-old A. rubra stand that colonized following a clear cut of $P$. menziesii / Tsuga heterophulla (Douglas fir/western hemlock) forest to be between 940 and $1130 \mathrm{mg} \mathrm{kg}^{-1}$ in the upper $15 \mathrm{~cm}$ of soil.

The first year root:shoot ratio of biosolid amended trees $(0.45 \pm 0.07)$ and control trees $(0.47$ $\pm 0.09)$ were both lower than the urea treatment $(0.60$ $\pm 0.13)$. The average total tree biomass of the biosolid, control and urea treatment trees was; $33 \pm 14 \mathrm{~g}, 14 \pm$ $11 \mathrm{~g}$ and $7 \pm 3 \mathrm{~g}$, respectively. Although Troelstra et al. (1992) found the addition of available $\mathrm{N}$ to increase 
the biomass of $A$. incana, during the first year of this study adding urea to the soil actually reduced tree growth, and it appears that at the highest rate of urea application the reduced yield seen in this study may have been partially related to $\mathrm{NH}_{3}$ toxicity.

\section{Foliar N}

During both years of the study foliar $\mathrm{N}$ was higher in trees grown in the biosolids amended soils than other treatments (Figure 3). This difference was most pronounced during the first year of the study with foliar $\mathrm{N}$ in trees grown with biosolids averaging $40 \pm 1 \mathrm{~g} \mathrm{~kg}^{-1}$ for comparison to $26 \pm 1 \mathrm{~g} \mathrm{~kg}^{-1}$ for the control and $27 \pm 1 \mathrm{~g} \mathrm{~kg}^{-1}$ for the urea treated soils. Foliar $\mathrm{N}$ for trees in urea treatments decreased with increasing rate of amendment. The first year trees growing in the 140 and $280 \mathrm{~kg} \mathrm{ha}^{-1}$ urea treatments, which had no detectable ARA activity, also had equivalent foliar $\mathrm{N}$ concentrations in relation to control trees indicating that the trees were able to utilize added soil available N. However, decreased foliar $\mathrm{N}$ of trees grown in the $560 \mathrm{~kg} \mathrm{ha}^{-1}$ urea treatment, along with reduced shoot biomass, may again indicate $\mathrm{NH}_{3}$ toxicity.

For the second year, trees grown in biosolids amended soil had foliar $\mathrm{N}$ concentrations of $23 \pm 2 \mathrm{~g}$ $\mathrm{kg}^{-1}$ as compared to $17 \pm 3 \mathrm{~g} \mathrm{~kg}^{-1}$ for the control and $19 \pm 3 \mathrm{~g} \mathrm{~kg}^{-1}$ for the urea amended soils. Foliar $\mathrm{N}$ concentration for trees grown with urea were similar to the control during the second year of the study when

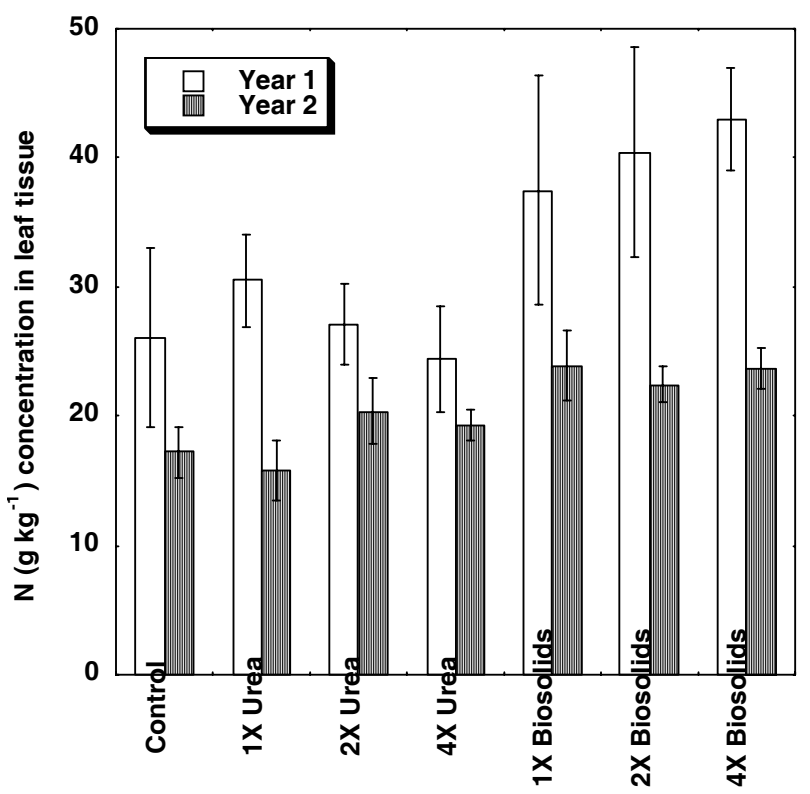

Figure 3 - Foliar N for Alnus rubra collected for both years of the study. Means \pm standard deviation are presented. Trees were fertilized with urea or municipal biosolids applied to provide one, two or four times the estimated $\mathrm{N}$ demand prior to planting. available $\mathrm{N}$ was depleted from the soil. Second year foliar N, in combination with higher rates of ARA activity, indicate that at this time Frankia was supplying $\mathrm{N}$ for the urea trees. The first year foliar $\mathrm{N}$ results for all trees were higher than the second year when soil $\mathrm{N}$ was also higher, indicating that Alnus were utilizing added soil $\mathrm{N}$. The higher foliar $\mathrm{N}$, rates of $\mathrm{N}$ fixation and shoot biomass of trees grown with biosolid amendments indicate that the $\mathrm{N}$ demand of trees was not being met entirely by Frankia or biosolids, but by a combination of Frankia and biosolids $\mathrm{N}$ concurrently. Urea trees appeared to only utilize either urea or Frankia N, not a combination of the two, the reduced growth and resulting $\mathrm{N}$ demand of the trees in the urea treatments may have been the result of a nutrient deficiency. In comparison, Compton et al. (1997) did not see a difference in foliar $\mathrm{N}$ when comparing two stands of $A$. rubra between soils with differing $\mathrm{P}$ and $\mathrm{pH}$, indicating that Frankia was able to supply the difference, but did find trees from lower P soils to also have lower foliar $\mathrm{P}, \mathrm{Ca}$, and $\mathrm{Mg}$ in addition to lower shoot biomass. In another study, Beaupied et al. (1990) found that the majority of leaf $\mathrm{N}$ in $A$. glutinosa came from symbiotically fixed $\mathrm{N}$, even if there was available $\mathrm{N}$ in the soil, as shown by rates of $\mathrm{N}$ fixation and soil mineral $\mathrm{N}$ concentrations. Levels of available $\mathrm{N}$ in that study ( 2-20 mg NO${ }_{3}^{-} \mathrm{kg}^{-1}$ soil, $\sim 2-12 \mathrm{mg} \mathrm{NH}_{4}^{+}$ $\mathrm{kg}^{-1}$ soil) were lower than levels in this study.

\section{CONCLUSION}

The Alnus/Frankia relationship for responses to $\mathrm{N}$ added in the different forms of urea and biosolids showed positive effects resulting from the addition of biosolids and little response to added urea. Biosolids treated trees had higher shoot biomass, foliar $\mathrm{N}$, and rates of $\mathrm{N}$ fixation than the urea and control trees. Urea inhibited rates of $\mathrm{N}$ fixation the first year, and had a negative impact on growth response. For low productivity soils, land application of biosolids to A. rubra appears to be an efficient method to maximize yield response. Although it was beyond the scope of this study to measure effects of $\mathrm{NO}_{3}^{-}$leaching, the high growth rate observed by trees grown in the biosolids amended soils suggests that $\mathrm{N}$ demand may have been high enough to reduce the potential for nitrate leaching.

\section{ACKNOWLEDGEMENTS}

This study was funded through a grant from King County and the Northwest Biosolids Management Association. 


\section{REFERENCES}

BEAUPIED, H.; MOIROUD, A.; DOMENACH, A.-M.; KURDALI, F.; AND LENSI, R. Ratio of fixed and assimilated nitrogen in a black alder (Alnus glutinosa) stand. Canadian Journal of Forest Research, v.20, p.1116-1119, 1990.

BINKLEY, D.; SENOCKB, R.; CROMACK, K. Phosphorus limitation on nitrogen fixation by Facaltaria seedlings. Forest Ecology and Management, v.186, p.171-176, 2003.

BREMNER, J.M. Nitrogen - total. In: BARTELS, J.M.; BIGHAM, J.M.; SPARKS, D.L.; PAGE, A.L.; HELMKE, P.A.; LOEPPERT, R.H.; SOLTANPOUR, P.N.; TABATABAI, M.A.; JOHNSTON, C.T.; SUMNER, M.E. (Ed.) Methods of soil analysis. Part 3. Chemical methods. Madison: SSSA; ASA, 1996. p.1085-1089.

BUSSE, M.D. Suitability and use of the $15 \mathrm{~N}$-isotope dilution method to estimate nitrogen fixation by actinorhizal shrubs. Forest Ecology and Management, v.136, p.85-95, 2000.

COMPTON, J.E.; COLE, D.W. Phosphorus cycling and soil $\mathrm{P}$ fractions in Douglas-fir and red alder stands. Forest Ecology and Management, v.110, p.101-112, 1998.

COMPTON, J.E.; COLE, D.W.; HOMANN, P.S. Leaf element concentrations and soil properties in first- and second-rotation stands of red alder (Alnus rubra). Canadian Journal of Forest Research, v.27, p.662-666, 1997.

CÔTÉ, B.; DAWSON, J.O. Effects of temperature regime and fertilization on nitrogenase activity of black alder seedlings during autumn in Illinois, USA. Canadian Journal of Forest Research, v.19, p.1644-1647, 1989.

DAIMON, H.; YOSHIOKA, M. Responses of root nodule formation and nitrogen fixation activity to nitrate in a split-root system in Peanut (Arachis hypogaeae L.). Journal of Agronomy and Crop Science, v.187, p.89-95, 2001.

FUJIKAKE, H.; YASHIMA, H.; SATO, T.; OHTAKE, N.; SUEYOSHI, K.; OHYAMA, T. Rapid and Reversible Nitrate Inhibition of Nodule Growth and N2 Fixation Activity in Soybean (Glycine $\max$ (L.) Merr.). Soil Science and Plant Nutrition, v.48, p.211-217, 2002.

GENTILI, F.; HUSS-DANELL, K. Local and systemic effects of phosphorus and nitrogen on nodulation and nodule function in Alnus incana. Journal of Experimental Botany, v.54, p.27572767, 2003.

HARDY, R.W.F.; BURNS, R.C.; HOLSTEN, R.D. Applications of the acetylene-ethylene assay for measurement of nitrogen fixation. Soil Biology and Biochemistry, v.5, p.47-81, 1973.

HENRY, C.L.; COLE, D.W.; HARRISON, R.B. Nitrate leaching from fertilization of three douglas-fir stands with biosolids. In: THE FOREST ALTERNATIVE SYMPOSIUM, Seattle, 2000. Proceedings. Seattle, 2000. p.83-88.

HENRY, C.L.; SULLIVAN, D.; RYNK, R.; DORSEY, K.; COGGER, C. Managing nitrogen from biosolids. Seattle: Washington State Department of Ecology, 1999. 57p.

HUSS-DANELL, K.; GENTILI, F.; VALVERDE, C.; WALL, L.; WIKLUND, A. Phosphorus is important in nodulation of actinorhizal plants and legumes. In: FINAN, T.M.; O'BRIAN, M.R.; LAYZELL, D.B.; VESSEY, J.K.; NEWTON, W. (Ed.). Nitrogen fixation global perspectives. Hamilton: Oxford University Press, 2001. p.163-165.

KEENEY, D.R.; NELSON, D.W. Nitrogen - inorganic forms. In: PAGE, A.L. (Ed.) Methods of soil analysis. Part 2. Chemical and microbiological properties. Madison: ASA; SSSA, 1982. p.643-649.

KUO, S. Phosphorus. In: BARTELS, J.M.; BIGHAM, J.M.; SPARKS, D.L.; PAGE, A.L.; HELMKE, P.A.; LOEPPERT, R.H.; SOLTANPOUR, P.N.; TABATABAI, M.A.; JOHNSTON, C.T.; SUMNER, M.E. (Ed.) Methods of soil analysis. Part 3 Chemical methods. Madison: SSSA; ASA, 1996.

MARTIN, K.J.; POSAVATZ, M.J.; MYROLD, D.D. Nodulation potential of soils from red alder stands covering a wide age range. Plant and Soil, v.254, p.187-192, 2003.
MCNEILL, A.M.; ZHU, C.; FILLERY, I.R.P. Use of in situ $15 \mathrm{~N}-$ labelling to estimate the total below-ground nitrogen of pasture legumes in intact soil-plant systems. Australian Journal of Agricultural Research, v.48, p.295-304, 1997.

MONACO, P.; CHING, K.; CHING, T. Host-endophyte effects on biomass production and nitrogen fixation in Alnus rubra actinorhizal symbiosis. Botanical Gazette, v.143, p.298-303, 1982.

MYROLD, D.D.; RUESS, R.W.; KLUG, M.J. Dinitrogen fixation. In: ROBERTSON, P.; COLEMAN, D.; BLEDSOE, C.; SOLLINS, P. (Ed.) Standard soil methods for long-term ecological restoration. New York: Oxford University Press, 1999. p.241257.

NATURAL RESOURCES CONSERVATION SERVICE - NRCS. Washington: State Soil Survey Report, 2004. Available in: http:/ /www.wa.nrcs.usda.gov.

NELSON, D.W.; SOMMERS, L.E. Total carbon, organic carbon, and organic matter. In: BARTELS, J.M.; BIGHAM, J.M.; SPARKS, D.L.; PAGE, A.L.; HELMKE, P.A.; LOEPPERT, R.H.; SOLTANPOUR, P.N.; TABATABAI, M.A.; JOHNSTON, C.T.; SUMNER, M.E. (Ed.) Methods of soil analysis. Part 3. Chemical methods. Madison: SSSA; ASA, 1996. p.961-1010.

O'CONNOR, G.A.; SARKAR, D.; BRINTON, S.R.; ELLIOTT, H.A.; MARTIN, F.G. Phytoavailability of biosolids-phosphorus. Journal of Environmental Quality, v.33, p.703-712, 2004.

OLIVERA, M.; TEJERA, N.; IRIBARNE, C.; OCANA, A.; LLUCH, C. Growth, nitrogen fixation and ammonium assimilation in common bean (Phaseolus vulgaris): effect of phosphorus. Physiologia Plantarum, v.121, p.498-505, 2004.

REDDELL, P.; YUN, Y.; SHIPTON, W.A. Do Casuarina cunninghamiana seedlings dependent on symbiotic N2 fixation have higher phosphorus requirements than those supplied with adequate fertilizer nitrogen? Plant and Soil, v.189, p.213219, 1997.

ROBERTSON, G.P.; SOLLINS, P.; ELLIS, B.G.; LAUTHA, K. Exchangeable Ions, $\mathrm{pH}$, and Cation Exchange Capacity. In: ROBERTSON, P.; COLEMAN, D.; BLEDSOE, C.; SOLLINS, P. (Ed.). Standard soil methods for long-term ecological research. New York: Oxford University Press, 1999. p.106-114.

ROJAS, N.S.; PERRY, D.A.; LI, C.Y.; GANIO, L.M. Interactions among soil biology, nutrition, and performance of actinorhizal plant species in the H.J. Andrews Experimental Forest of Oregon. Applied Soil Ecology, v.19, p.13-26, 2002.

ROTHE, A.; CROMACK, K.J.; RESH, S.C.; MAKINECI, E.; SON, Y. Soil carbon and nitrogen changes under douglas-fir with and without red alder. Soil Science Society of America Journal, v.66, p.1988-1995, 2002.

RYTTER, L.; ARVEBY, A.S.; GRANHALL, U. Dinitrogen (C2H2) fixation in relation to nitrogen fertilization of grey alder (Alnus incana (L.) moench.) plantations in a peat bog. Biology and Fertility of Soils, v.10, p.233-240, 1991

SERA-IEG 17. Methods of phosphorus analysis for soils, sediments, residuals, and waters. Southern Cooperative Series Bulletin, n.396, 2000. Available in: http://www.soil.ncsu.edu/sera17/ publications/sera17-2/pm_cover.htm. Accessed at: 01/15/06.

SHEARER, G.; KOHL, D.H.; VIRGINIA, R.A.; BRYAN, B.A.; SKEETERS, J.L.; NILSEN, E.T.; SHARIFI, M.R.; RUNDEL, P.W. Estimates of N2-fixation from variation in the natural abundance of $15 \mathrm{~N}$ in Sonoran Desert ecosystems. Oecologia, v.56, p.365-373, 1983.

SIDIRAS, N.; AVGOULAS, C.; BILALIS, D.; TSOURGRIANIS, N. Effects of tillage and fertilization on biomass, roots, Naccumulation and nodule bacteria of vetch (Vicia sativa cv. Alexander). Journal of Agronomy and Crop Science, v.182, p.209-216, 1999

SPSS INC. SPSS 12 for Windows. Chicago, Il., 2003.

TEKLEHAIMANOT, Z.; MARTIN, R. Diurnal and seasonal patterns of nitrogenase activity of red alder in comparison with white clover in silvopastoral agroforestry systems. Biology and Fertility of Soils, v.28, p.267-270, 1999. 
TROELSTRA, S.R.; WAGENAAR, R.; SMANT, W. Growth of Actinorhizal Plants as Influenced by the Form of $\mathrm{N}$ with Special Reference to Myrica gale and Alnus incana. Journal of Experimental Botany, v.43, p.1349-1359, 1992.

ULIASSI, D.D.; RUESS, R.W. Limitations to Symbiotic Nitrogen Fixation in Primary Succession on the Tanana River Floodplain. Ecology, v.83, p.88-103, 2002.

USEPA. SW-846 - Test methods for evaluating solid waste Physical/chemical methods. Method 3050B: Acid digestion of sediments, sludges, and soils. Washington, DC, 1986.

VIEIRA, R.F. Sewage sludge effects on soybean growth and nitrogen fixation. Biology and Fertility of Soils, v.34, p.196-200, 2001.

VOISON, A.S.; SALON, C.; MUNIER-JOLAIN, N.G.; NEY, B. Effect of mineral nitrogen nutrition and biomass partitioning between the shoot and roots of pea (Pisum sativum L.). Plant and Soil, v.242, p.251-262, 2002.
WALL, L.G.; HELLSTEN, A.; HUSS-DANELL, K. Nitrogen, phophorus, and the ratio between them affect nodulation in Alnus incana and Trifolium pratense. Symbioses, v.29, p.91$105,2000$.

WEAVER, R.W.; DANSO, S.K.A. Dinitrogen fixation. In: WEAVER, R.W.; ANGLE, J.S.; BOTTOMLEY, P.S. (Ed.). Methods of soil analysis. Part 2. Chemical and microbiological properties. Madison: SSSA; ASA, 1994. p.1019-1023.

Received March 07, 2006

Accepted June 15, 2006 